\title{
AIDED PHYTOSTABILIZATION OF COPPER CONTAMINATED SOILS WITH L. PERENNE AND MINERAL SORBENTS AS SOIL AMENDMENTS
}

\author{
Maja RADZIEMSKA ${ }^{1}$ \\ Warsaw University of Life Sciences - SGGW, Warszawa, Poland
}

\begin{abstract}
The present study was designed to assess phytostabilization strategies for the treatment of soil co-contaminated by increasing levels of copper with the application mineral amendments (chalcedonite, zeolite, dolomite). From the results it will be possible to further elucidate the benefits or potential risks derived from the application of different types of mineral amendments in the remediation of a copper contaminated soil. A glasshouse pot experiment was designed to evaluate the potential use of different amendments as immobilizing agents in the aided phytostabilization of $\mathrm{Cu}$-contaminated soil using ryegrass (Lolium perenne $\mathrm{L}$.). The content of trace elements in plants and total in soil, were determined using the method of spectrophotometry.

All of the investigated element contents in the tested parts of L. perenne were significantly different in the case of applying mineral amendments to the soil, as well as increasing concentrations of copper. The greatest average above-ground biomass was observed for soil amended with chalcedonite. In this experiment, all analyzed metals accumulated predominantly in the roots of the tested plant. In general, applying mineral amendments to soil contributed to decreased levels of copper concentrations.
\end{abstract}

Keywords: aided phytostabilization, metal-contaminated soil, risk minimization, Lolium perenne $\mathrm{L}$.

\footnotetext{
${ }^{1}$ Corresponding author: Warsaw University of Life Sciences - SGGW, Faculty of Civil and Environmental Engineering, Nowoursynowska st 159, 02-776 Warszawa, Poland, e-mail: maja_radziemska@sggw.pl, tel. +48225935370
} 


\section{INTRODUCTION}

Contamination of soil with the heavy metals has become a serious problem throughout the world, causing the reduction of agricultural yield and harmful effects on human health by entering the food chain [27, 11, 1]. Copper is introduced into the soil and ground water through various products of human activity, including: fertilizers, fungicides and pesticides, sludge, pig wastes, emissions from municipal wastes, mining and residues from metalliferous mines $[9,2,4]$. Despite being an essential element and acting as a co-factor in numerous enzymes, at higher concentrations, copper is highly toxic to plants and microorganisms [22,6]. In fact, one of the most complicated issues for environmental engineering is to detoxify soils polluted with copper [16].

Main principles of phytoremediation are (1) improvement of the topsoil quality as an important ecological factor (2) phytoimmobilization of the heavy metals, (3) phytoextraction of heavy metals into roots and shoots of the plants, (4) minimization of seepage water formation by evapotranspiration and new soil formation [33].

Phytostabilization is a simple, cost-effective and less environmentally invasive approach to stabilize and reduce the bioavailability of contaminants by using plants [28]. It is important to mention that phytostabilization is not a technology for real clean-up of contaminated soils, but a management strategy for inactivating (stabilizing) heavy metals with a labile pool in excess leading to biological effects [7, 19]. Aided phytostabilization is a technique which relies on the application of metal immobilizing additives (mineral/organic) to the soil, along with appropriately selected plant species. It is important to gain an understanding of the chemical composition of plants growing on the contaminated areas [38].

In connection with the above, studies were assumed whose aim was to determine the influence of chalcedonite, zeolite, and dolomite applied to soil contaminated with copper on the effectiveness of the process of aided phytostabilization by determining: mobility and redistribution of copper on $L$. perenne and the concentration of copper in soil.

\section{MATERIALS AND METHODS}

\subsection{Experiment set-up}

The experiments were conducted in $5.0 \mathrm{~kg}$ polyethylene pots using a noncontaminated soil collected at a depth of about $0-20 \mathrm{~cm}$ in the agricultural area. The soil was characterized for several parameters (Tab. 1). The methods used 
for the determination of organic matter content in the soil Tiurin's method have been described by [17]. The ammonium content of the soil was determined with an ammonia electrode as ammonium formed by Kjeldahl digestion [5]. The Kappen method [12] was employed to estimate the hydrolyticacidity (HAC) and total exchangeable bases (TEB-K $\mathrm{K}^{+}, \mathrm{Na}^{+}, \mathrm{Ca}^{2+}$, and $\mathrm{Mg}^{2+}$ ) of the used soil. Cation exchange capacity (CEC) from the formula:CEC=HAC+TEB and percentage base saturation $(\mathrm{V})$ from the for-mula: $\mathrm{BS}=100 \mathrm{TEB} / \mathrm{CEC}^{-1}$. Soil $\mathrm{pH}$ (with a glass electrode using a 1:1 sample/water ratio). Electrical conductivity (EC) measured with a HandylabpH/LF 12 conductometer (Schott, Germany), in a 1:2 soil/deionizedwater suspension (w/v). Phosphorus and potassium content Egner-Riehm method [28], and magnesium content - atomicabsorption spectrometry method following extraction using the Schachtschabel method [14].

Table 1. Selected physico-chemical parameters of soil used for pot experiment

\begin{tabular}{|l|l|}
\hline Soil parameter & Value \\
\hline $\mathrm{pH}$ & 4.92 \\
\hline Hydrolytic acidity $\left(\mathrm{mmol} \cdot \mathrm{kg}^{-1}\right)$ & 31.21 \\
\hline Sum of exchangeable bases $\mathrm{Ca}^{2+}, \mathrm{Mg}^{2+}, \mathrm{K}^{+}, \mathrm{Na}^{+}\left(\mathrm{mmol}_{\mathrm{kg}} \mathrm{k}^{-1}\right)$ & 61.10 \\
\hline Cation exchange capacity $\left(\mathrm{mmol} \mathrm{kg}^{-1}\right)$ & 94.20 \\
\hline Base saturation $(\%)$ & 65.20 \\
\hline Total N $\left(\mathrm{g} \cdot \mathrm{kg}^{-1}\right)$ & 1.22 \\
\hline Organic carbon $\left(\mathrm{g} \cdot \mathrm{kg}^{-1}\right)$ & 7.42 \\
\hline $\mathrm{N}-\mathrm{NH}_{4}^{+}\left(\mathrm{mg} \mathrm{kg}^{-1}\right)$ & 20.32 \\
\hline $\mathrm{N}-\mathrm{NO}_{3}^{-}\left(\mathrm{mg} \cdot \mathrm{kg}^{-1}\right)$ & 10.01 \\
\hline Extractable P $\left(\mathrm{mg} \cdot \mathrm{kg}^{-1}\right)$ & 43.20 \\
\hline Extractable K $\left(\mathrm{mg} \cdot \mathrm{kg}^{-1}\right)$ & 8.72 \\
\hline Extractable Mg $\left(\mathrm{mg}^{-1} \mathrm{~kg}^{-1}\right)$ & 31.2 \\
\hline $\mathrm{Cu}\left(\mathrm{mg} \cdot \mathrm{kg}^{-1}\right)$ & 8.20 \\
\hline
\end{tabular}

Soil/amendments mixtures were placed into pots and sown perennial ryegrass (Lolium perenne L.) variety Bokser on the surface. The plants were watered every other day to $60 \%$ of the maximum water holding capacity of the soil by adding deionized water. Soil was artificially polluted with aqueous solutions of copper in the form of copper (II) chloride dehydrate $\left(\mathrm{CuCl}_{2} \cdot 2 \mathrm{H}_{2} \mathrm{O}\right.$, produced at the POCh, Gliwice) in the following doses ( $\mathrm{mg} / \mathrm{kg}$ of soil): 0 (control), 150, 300, and 600, and was fertilized with amacro- and micronutrient fertilizer mixture $(\mathrm{g} / \mathrm{kg})$ containing $\mathrm{N}-26 \%, \mathrm{P}_{2} \mathrm{O}_{5}-12 \%, \mathrm{~K}_{2} \mathrm{O}-26 \%$, B- $0.013 \%$, Cu- $0.025 \%$, Fe$0.05 \%$, Mn- $0.25 \%$, and Mo- $0.20 \%$. The soil samples were thoroughly mixed and were allowed to stabilize under natural conditions for two weeks before using as agrowth experiment. Mineral amendments (chalcedonite, zeolite, dolomite) was mixed in with the soil in the amount of $3.0 \%$ (each). Soils without copper and amendments $(0.0 \%)$ were designated as the control. At the 
end of the experiment (approx. 45 days after seed sowing), plants were harvested, weighed and separated into above-ground patrs and roots.

\subsection{Plant and soil elemental analysis}

Plant material was carefully washed with deionized and further ultrapure water to remove soil particles, and then air-dried at room temperature. Before analysis, theplants were powdered using an analytical mill (Retsch type ZM300, Hann, Germany) and kept at ambient temperature prior to thechemical analyses. A representative subsample was mineralized in nitric acid $\left(\mathrm{HNO}_{3}\right.$ p.a.) with a concentration of $1.40 \mathrm{~g} / \mathrm{cm}$ and $30 \% \mathrm{H}_{2} \mathrm{O}_{2}$ using a microwave oven (Milestone Start D, Italy). After filtration, the digestion products were adjusted to $100 \mathrm{~mL}$ volume with deionized water. Extracts were analyzed for total copper concentrations were determined by Atomic Absorption Spectrometry method using an iCE-3000 spectrophotometer (Thermo Scientific, USA). Copper in soil was analyzed using U.S. EPA method 3051.

\subsection{Statistical analysis}

Experiments were performed in triplicates and the values presented as the means \pm standard deviation. The data were analysed using Statistica software (version 10.0, San Diego, CA, USA). Significant differences $(\mathrm{p}<0.05)$ between the mean values of different treatments were compared and evaluated using Duncan's multiple range test.

\section{RESULTS AND DISCUSSION}

The effects of chalcedonite, zeolite, and dolomite on the biomass production of Lolium perenne L. grown in a copper contaminated soils are shown in Fig. 1. In our study, the biomass of plants in the control series (without the addition of amendments to copper-contaminated soil) decreased by $9 \%$ in the treatment with the lowest copper dose $(150 \mathrm{mg} / \mathrm{kg}$ soil) to $40 \%$ in the treatment with the highest copper dose $(600 \mathrm{mg} / \mathrm{kg}$ soil). The results of this study and published data [20, 35, 39] suggest that copper's adverse influence on crop yield is determined not only by copper concentration in soil, but also by the applied soil amendments. The greatest average above-ground biomass was observed in cases of amending soil with chalcedonite (38\%) and zeolite (43\%) as compared to not applying any of these substances to the soil. Several authors have reported the effectiveness of lime materials to enhance revegetation, or increase plant survival and growth on contaminated soils by copper [32, 15]. The growth of rye seedlings, in particular the above-ground parts of the analyzed plants, was also stilted under exposure to increasing doses of copper [13]. In the work of Wyszkowski and Radziemska [36, 37, 35], Radziemska and Mazur [20] zeolite 
increased the average yield of aerial parts of oats, spring barley, spring rapeseed and maize grown in soil polluted with heavy metals. There are some reports indicating that rice seed biomass increases in bentonite-treated soil [29].

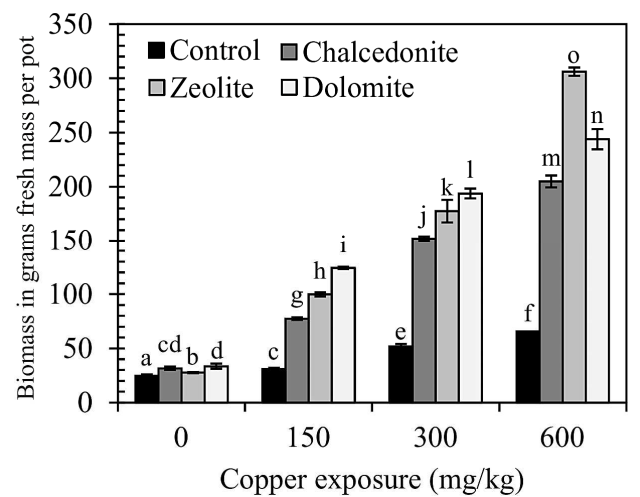

Fig. 1. Effect of copper and various mineral sorbents on the aboveground biomass of Lolium perenne L., in grams fresh mass per pot. Error bars are \pm standard error $(n=3)$.

Bars indicated by the different letter are significantly different $(\mathrm{P}<0.05)$ according toTukey's test

The chemical mobility and uptake of metal ions by the plants can be affected by microbial activities, rhizospheres and roots [18]. The chelator compounds inside plant tissue play an important role in the toleration, sequestration and transportation of contaminants [30]. Plants used in the phytostabilization technique should store trace elements in root tissues and be characterized by a limited ability of translocating them to the above-ground parts [40]. As shown in Fig. 2, the accumulation of copper contentwas much higher in roots than in shoots, and this major advantage indicates the potential of Lolium perenne $\mathrm{L}$. as a phytostabilizer. The normal concentration of copper in plant material ranges from 5 to $25 \mathrm{mg} / \mathrm{kg}$ [2]. In the control, copper concentrations (in $\mathrm{mg} / \mathrm{kg}$ dry weight) varied between 7.61-55.10 in shoots and between 24.53-306.14 in roots. Data found in literature confirm the existence of a correlation between total copper content in soil and its concentration in plants [34]. According to Tiecher et al. [31] copper accumulation occurred predominantly in the young grapevine roots, with low translocation to the shoots. In the control series (without additives), a positive correlation between the copper content in tested plant and the increasing contamination of soil with copper occurred. The highest reduction of copper contents (39\%) - was observed in the above-ground parts of the tested plant species grown in soil containing dolomite, as compared to the uncontaminated soil. Compared with the control treatment, the chalcedonite and zeolite treatments significantly increased copper concentration in plant roots as compared to pots to which additives had not been added. These results were 
similar to another experiment conducted by Radziemska et al. [25, 23] where the heavy metal contents in the above-ground parts of maize, Indian mustard, and ryegrass were affected by the application of mineral sorbents (i.e. zeolite, halloysite, limestone, chalcedonite and dolomite).

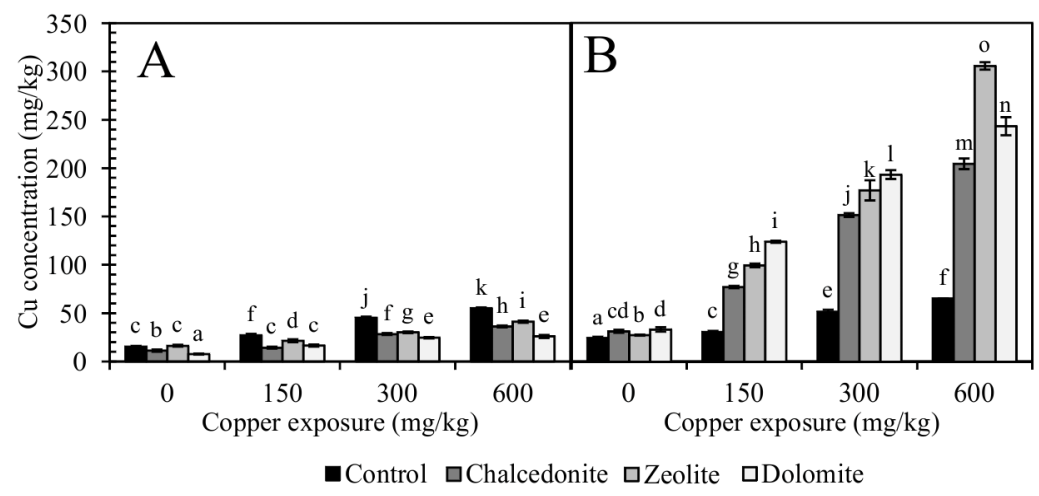

Fig. 2. Copper concentration ( $\mathrm{mg} / \mathrm{kg}$, dry weight basis) in the above-ground part (a) and roots (b) of Lolium perenne L. at the end of the trial. Error bars are \pm standarderror $(\mathrm{n}=$ 3). Bars marked with different letters differ significantly for the same $\mathrm{Cu}$ exposure $(\mathrm{P}<$ 0.05 ) according to the Duncan test

The total content of heavy metals in the soil is, in addition to $\mathrm{pH}$, one of the most important factors influencing the absorption of heavy metals and their content in a plant. In the presented research, the $\mathrm{pH}$ of soil solutions increased following the addition of mineral sorbents (control: $5.71 \pm 0.05$; chalcedonite: $6.23 \pm 0.05$; zeolite $6.78 \pm 0.04$ : dolomite: $7.12 \pm 0.05$ ). In the series lacking mineral additives, increasing doses of copper contamination caused a successive increase in the $\mathrm{pH}$ of soil. The greatest increase was $0.89 \mathrm{pH}$ units, observed after dolomite was added to the soil. The best growth in trace elements contaminated soils occurred at $\mathrm{pH} 6.0$ to 5.5 - the reason might be the only slight solubility of toxic metals in the soil solution under these conditions [10]. Metal solubility and mobility increased as $\mathrm{pH}$ decreased [8]. As reported by Wyszkowski and Radziemska [37], the addition of zeolites and $\mathrm{CaO}$ reduced copper solubility in the soil by forming stable complexes. Soil copper concentrations have been presented in Fig. 3. In this study, the application of zeolite and chalcedonite led to a significant decrease in total copper concentrations in soil as compared to the control pots. This suggests that soils treated with the application of mineral sorbents exhibit a greater ability to desorb copper from the soil in comparison to soil without amendments. In an earlier experiment conducted by Radziemska and Mazur [21], the addition of 
zeolite to soil contaminated with heavy metals caused a significant decrease of copper in the soil.

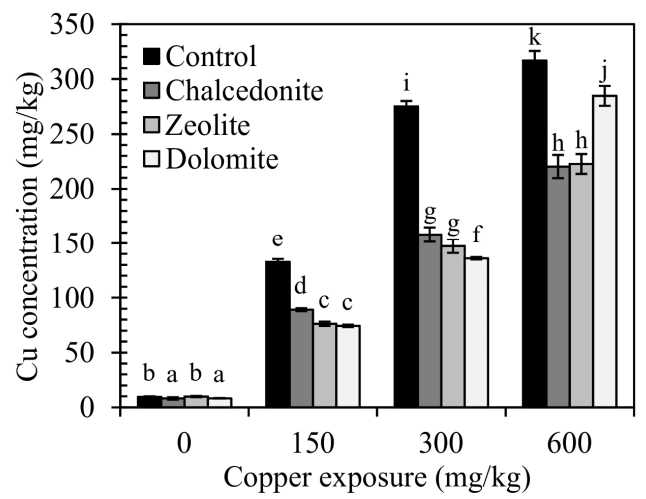

Fig. 3. $\mathrm{Cu}$ concentrations in soil with the different soil treatments (mean $\pm \mathrm{SD}, \mathrm{n}=3$ ).

Values in columns marked with the same letter do not differ significantly (Duncan test, $\mathrm{P}>0.05$ )

\section{CONCLUSIONS}

Phytostabilization assisted by mineral sorbents was used to immobilize a copper-contaminated soil in a pot experiment. The present study clearly showed that soil aided phytostabilization techniques can be useful for alleviating the adverse effects of copper deposition in the food chain. The efficiency of phytostabilization depends on the plant species and soil amendments used. In the presented research, the greatest average above-ground biomass of Lolium perenne L. was observed in cases of amending soil with zeolite. Copper accumulated in the roots, thereby reducing its toxicity to the aerial parts of the tested plant. The application of dolomite to soil contaminated with copper contributed to a significant increase in $\mathrm{pH}$ values. The application of zeolite and chalcedonite turned out to be the most effective when it came to reducing total copper content in the soil.

\section{REFERENCES}

1. Adamcová D., Vaverková M.D., Bartoň S., Havlíček Z., Břoušková E.: Soil contamination in landfills: a case study of a landfill in Czech Republic, Solid Earth, 7 (2016) 239-247.

2. Ariyakanon N., Winaipanich B.: Phytoremediation of copper contaminated soil by Brassica juncea (L.) Czern and Bidens alba (L.) DC. var. radiate, Journal of Scientific Research Chulalongkorn University, 31 (2006) 49-56. 
3. Avkopashvili G., Avkopashvili M., Gongadze A., Tsulukidze M., Shengelia E.: Determination of $\mathrm{Cu}, \mathrm{Zn}$ and $\mathrm{Cd}$ in soil, water and food products in the vicinity of RMG gold and copper mine, Kazreti, Georgia, Annals of Agrarian Science, 15, 2 (2017) 269-272.

4. Balint R., Said-Pullicino D., Ajmone-Marsan F.: Copper dynamics under alternating redox conditions is influenced by soil properties and contamination source, Journal of Contaminant Hydrology, 173 (2015) 8391.

5. Bremner J.M.: In: Black, C.A. (Ed.), Methods of Soil Analysis. Am. Soc. Agron., Madison, 1256-1286, 1965.

6. Eduok S., Martin B., Villa R., Nocker A., Jefferson B., Coulon F.: Evaluation of engineered nanoparticle toxic effect on wastewater microorganisms: Current status and challenges, Ecotoxicology and Environmental Safety, 95 (2013) 1-9.

7. Ellili A., Rabier J., Prudent P., Salducci M.D., Heckenroth A., Lachaâl M., Laffont-Schwob I.: Decision-making criteria for plant-species selection for phytostabilization: Issues of biodiversity and functionality, Journal of Environmental Management, 201 (2017) 215-226.

8. Ettler V., Tomásová Z., Komárek M., Mihaljevi M., Sebek O., Michálková $\mathrm{Z}$.: The pH-dependent long-term stability of an amorphous manganese oxide insmelter-polluted soils: implication for chemical stabilization of metals andmetalloids, Journal of Hazardous Materials, 286 (2015) 386-394.

9. El Hadri H., Chéry P., Jalabert S., Lee A., Potin-Gautier M., Lespes G.: Assessment of diffuse contamination of agricultural soil by copper in Aquitaine region by using French national databases, Science of The Total Environment, 441, 15 (2012) 239-247.

10. Kabata-Pendias A., Pendias A.: Trace elements in soil and plants. 3rd ed. CRC Press, New York, 2001.

11. Karak T., Bora K., Paul R.K., Das S., Khare P., Dutta A.K., Boruah R.K.: Paradigm shift of contamination risk of six heavy metals in tea (Camellia sinensis L.) growing soil: A new approach influenced by inorganic and organic amendments, Journal of Hazardous Materials, 338 (2017) 250-264.

12. Klute A. Methods of Soil Analysis. American Society of Agronomy. Agronomy Monograph, Madison, 1996.

13. Kubicka H., Jaron N.: The action of copper ions on the growth of inbred lines of rye seedlings (Secale cereale L.), Environmental Protection and Natural Resources, 48 (2016) 96-103 [in Polish].

14. Lityński T., Jurkowska H., Gorlach E.: Chemical and Agriculture Analysis. PWN, Warszawa, 129-132 (in Polish) 1976.

15. Madejon E., de Mora A.P., Felipe E., Burgos P., Cabrera F.: Soil amendments reduce trace element solubility in a contaminated soil and 
allow regrowth of natural vegetation, Environmental Pollution, 139 (2006) 40-52.

16. Juan M., Mancilla-Leytón M., José Navarro-Ramos M.J., Muñoz-Vallés S., M., Figueroa E., Cambrollé J.: Evaluation of the potential of Atriplex halimus stem cuttings for phytoremediation of metal-polluted soils, Ecological Engineering, 97 (2016) 553-557.

17. Mocek A., Drzymała S.: Genesis, analysis and soil classification. Poznan Univ. Life Sci. (in Polish), 2010.

18. Moreno-Jiménez E., Sepúlveda R., Esteban E., Beesley L.: Efficiency of organic and mineral based amendments to reduce metal[loid]mobility and uptake (Lolium perenne) from a pyrite-waste contaminated soil, Journal of Geochemical Exploration, 174 (2017) 46-52.

19. Najeeb U., Ahmad W., Zia M.H., Zaffar M., Zhou W.: Enhancing the lead phytostabilization in wetland plant Juncus effusus L. through somaclonal manipulation and EDTA enrichm.ent, Arabian Journal of Chemistry, 10, 2 (2017) S3310-S3317.

20. Radziemska M., Mazur Z.: Chemical composition of spring rapeseed grown in copper-contaminated soil amended with halloysite and zeolite, Journal of Ecological Engineering, 18, 2 (2017) 38-43.

21. Radziemska M., Mazur Z.: Content of selected heavy metals in $\mathrm{Ni}$ contaminated soil following the application of halloysite and zeolite, Journal of Ecological Engineering, 17, 3 (2016) 125-133.

22. Radziemska M., Jeznach J., Mazur Z., Fronczyk J., Bilgin A.: Assessment of the effect of reactive materials on the content of selected elements in Indian mustard grown in Cu-contaminated soils, Journal of Water and Land Development, 28 (2016) 53-60.

23. Radziemska M., Mazur Z., Fronczyk J., Matusik J.: Co-remediation of Nicontaminated soil by halloysite and Indian mustard (Brassica juncea L.), Clay Minerals, 51 (2016) 489-497.

24. Radziemska M., Gusiatin Z.M., Bilgin A.: Potential of using immobilizing agents in aided phytostabilization on simulated contamination of soil with lead, Ecological Engineering, 102 (2017) 490-500.

25. Radziemska M., Mazur Z., Fronczyk J., Jeznach J.: Effect of zeolite and halloysite on accumulation of trace elements in maize (Zea Mays L.) in nickel contaminated soil, Fresenius Environmental Bulletin, 23, 12a (2014) 3140-3146.

26. Riehm H.: Die ammoniumlaktatessigsaure-methode zur bestimmung derleichtloeslichen phosphosaure in karbonathaltigen boden, Agrochimica 3, 49-65, 1958. 
27. Sas W., Głuchowski A., Radziemska M., Dzięcioł J., Szymański A.: Environmental and geotechnical assessment of the steel slags as a material for road structure, Materials, 8 (2015) 4857-4875.

28. Shutcha M.N., Faucon M.P., Kissi C.K., Colinet G., Mahy G., Luhembwe M.N., Visser M., Meerts P.: Three years of phytostabilisation experiment of bare acidic soil extremely contaminated by copper smelting using plant biodiversity of metal-rich soils in tropical Africa (Katanga, DR Congo), Ecological Engineering, 82 (2016) 81-90.

29. Sun Y., Li Y., Xu Y., Liang X., Wang L.: In situ stabilization remediation ofcadmium $(\mathrm{Cd})$ and lead $(\mathrm{Pb})$ co-contaminated paddy soil using bentonite, Applied Clay Science, 105-106 (2014) 200-206.

30. Sun Q., Wang X.R., Ding S.M., Yuan X.F.: Effects of exogenous organic chelators on phytochelatins production and its relationship with cadmium toxicity in wheat (Triticum aestivum L.) under cadmium stress, Chemosphere, 60, 1 (2005) 22-31.

31. Tiecher T.L., Tiecher T., Ceretta C.A., Ferreira P.A.A., Nicoloso F.T., Soriani H.H., De Conti L., Kulmann M.S.S., Schneider R.O., Brunetto G.: Tolerance and translocation of heavy metals in young grapevine (Vitis vinifera) grown in sandy acidic soil with interaction of high doses of copper and zinc, Scientia Horticulturae, 222 (2017) 203-212.

32. Ulriksen C., Ginocchio R., Mench M., Neaman A.: Lime and compost promote plant re-colonization of metal-polluted, acidic soils, International Journal of Phytoremediation, 14 (2012) 820-833.

33. Willscher S., Jablonski L., Fona Z., Rahmi R., Wittig J.: Phytoremediation experiments with Helianthus tuberosus under different $\mathrm{pH}$ and heavy metal soil concentrations, Hydrometallurgy, 168 (2017) 153-158.

34. Willscher S., Wittig J., Bergmann H., Büchel G., Merten D., Werner P.: Phytoremediation as an alternative way for the treatment of large, low heavy metal contaminated sites: application at a former uranium mining area, Advanced Materials Research, 71-73 (2009) 705-708.

35. Wyszkowski M., Radziemska M.: Effects of chromium (III and VI) on spring barley and maize biomass yield and content of nitrogenous compounds, Journal of Toxicology and Environmental Health, Part A, 73 (2010) 1274-1282.

36. Wyszkowski M., Radziemska M.: Assessment of tri- and hexavalent chromium phytotoxicity on Oats (Avena sativa L.) biomass and content of nitrogen compounds, Water Air and Soil Pollution, 244 (2013) 1619-1632.

37. Wyszkowski M., Radziemska M.: Influence of chromium (III) and (VI) on the concentration of mineral elements in oat (Avena sativa L.), Fresenius Environmental Bulletin, 22, 4 (2013) 979-986. 
38. Yang S.X., Liao B., Yang Z.H., Chai L.Y., Li J.T.: Revegetation of extremely acid mine soils based on aided phytostabilization: A case study from southern China, Science of The Total Environment, 562 (2016) 427434.

39. Zhang L., Pan Y., Lv W., Xiong Z.T.: Physiological responses of biomass allocation, root architecture, and invertase activity to copper stress in young seedlings from two populations of Kummerowia stipulacea (maxim.) Makino, Ecotoxicology and Environmental Safety, 104 (2014) 278-284.

40. Zhang S.J., Li T.X., Huang H.G., Zou T.J., Zhang X.Z., Yu H.Y., Zheng Z.C., WangY.D.: Cd accumulation and phytostabilization potential of dominantplants surrounding mining tailings, Environmental Science and Pollution Research, 19 (2012) 3879-3888.

\section{WSPOMAGANA FITOSTABILIZACJA GLEBY ZANIECZYSZCZONEJ MIEDZIĄ Z WYKORZYSTANIEM L. PERENNE I SORBENTÓW MINERALNYCH JAKO DODATKÓW}

\section{Streszczenie}

Niniejsze badania zostały przeprowadzone w celu oceny procesu wspomaganej fitostabilizacji gleby zanieczyszczonej wzrastającymi dawkami miedzi przy zastosowaniu dodatków mineralnych (chalcedonit, zeolit, dolomit). Na podstawie otrzymanych wyników badań można wyjaśnić korzyści jak i potencjalne zagrożenia wynikające ze stosowania różnego rodzaju dodatków mineralnych w celu immobilizacji zanieczyszczenia gleby miedzią. Eksperyment wazonowy został przeprowadzony z wykorzystaniem rośliny testowej jaką była życica trwała (Lolium perenne L.) odmiany Bokser. Zawartość miedzi w poszczególnych organach rośliny (część nadziemna, korzenie) oraz w glebie określono przy wykorzystaniu metody spektrofotometrii. Koncentracja miedzi w poszczególnych organach L. perenne zależała od rodzaju wprowadzonego do gleby dodatku mineralnego oraz dawki miedzi. Największy przyrost biomasy zaobserwowano $\mathrm{w}$ przypadku dodatku do gleby chalcedonitu. W przeprowadzonym eksperymencie miedź gromadziła się głównie w korzeniach rośliny testowej. Zastosowanie dodatków mineralnych miało tendencję do zmniejszania całkowitej zawartości miedzi w glebie, w porównaniu do kontroli.

Keywords: wspomagana fitostabilizacja, zanieczyszczenie gleby metalami ciężkimi, minimalizacja ryzyka, Lolium perenne $\mathrm{L}$.

Editor received the manuscript: 28.07.2017 